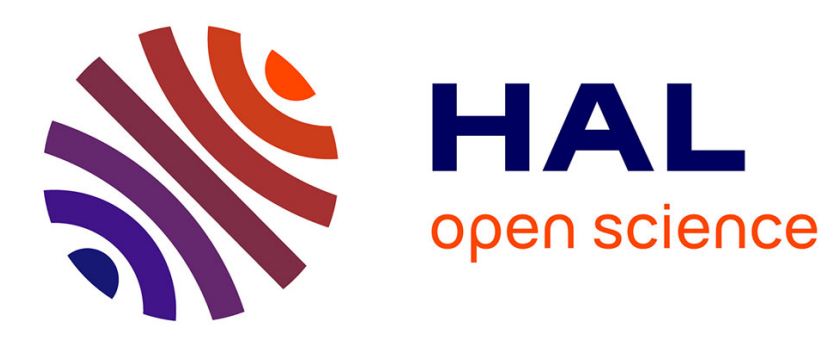

\title{
Dynamic recrystallization observed at the tool/chip interface in machining
}

\author{
Yannick Senecaut, Michel Watremez, Julien Brocail, Laurence
}

Fouilland-Paille, Laurent Dubar

\section{To cite this version:}

Yannick Senecaut, Michel Watremez, Julien Brocail, Laurence Fouilland-Paille, Laurent Dubar. Dynamic recrystallization observed at the tool/chip interface in machining. ESAFORM 2015, Apr 2015, Graz, Austria. pp.1223-1228, 10.4028/www.scientific.net/KEM.651-653.1223 . hal-01178171

\section{HAL Id: hal-01178171 \\ https://hal.science/hal-01178171}

Submitted on 1 Jun 2017

HAL is a multi-disciplinary open access archive for the deposit and dissemination of scientific research documents, whether they are published or not. The documents may come from teaching and research institutions in France or abroad, or from public or private research centers.
L'archive ouverte pluridisciplinaire HAL, est destinée au dépôt et à la diffusion de documents scientifiques de niveau recherche, publiés ou non, émanant des établissements d'enseignement et de recherche français ou étrangers, des laboratoires publics ou privés. 


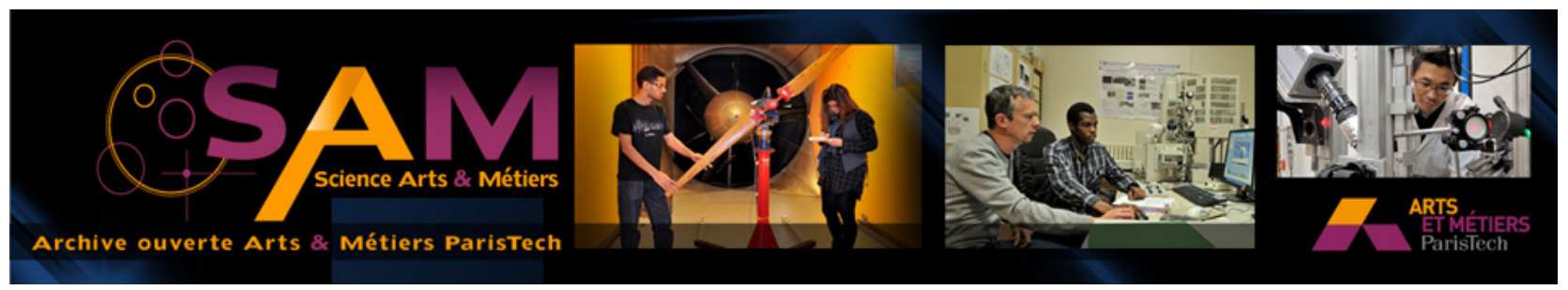

Science Arts \& Métiers (SAM)

is an open access repository that collects the work of Arts et Métiers ParisTech researchers and makes it freely available over the web where possible.

This is an author-deposited version published in: http://sam.ensam.eu

Handle ID: .http://hdl.handle.net/10985/9821

\section{To cite this version :}

Laurence FOUILLAND - Dynamic recrystallization observed at the tool/chip interface in machining - In: ESAFORM 2015, Autriche, 2015-04 - Key Engineering Materials (ESAFORM 2015) - 2015 


\title{
Dynamic recrystallization observed at the tool/chip interface in machining
}

\author{
Yannick Senecaut ${ }^{1,2,3, a}$, Michel Watremez ${ }^{1,2,3, \mathrm{~b}^{*}}$, Julien Brocail ${ }^{4, \mathrm{c}}$, \\ Laurence Fouilland-Paille ${ }^{5, d}$, Laurent Dubar ${ }^{1,2,3, e}$, \\ ${ }^{1}$ Univ Lille Nord de France, F-59000 Lille, France \\ ${ }^{2}$ UVHC, TEMPO EA 4542, F-59313 Valenciennes, France \\ ${ }^{3}$ Institut Carnots Arts, F-75013 Paris, France \\ ${ }^{4}$ Centre de Recherche de l'ESTACA, 2MCE, F-92532 Levallois-Perret, France \\ ${ }^{5}$ Arts et Métiers ParisTech, MSMP, F-51006 Châlons en Champagne, France \\ ayannick.senecaut@univ-valenciennes.fr, ${ }^{b}$ michel.watremez@univ-valenciennes.fr, \\ julien.brocail@estaca.fr, 'laurence.fouilland-paille@ensam.eu, \\ elaurent.dubar@univ-valenciennes.fr
}

\section{Keywords: Machining, Dynamic Recrystallization, Numerical Simulation}

\begin{abstract}
In numerical approaches for high speed machining, the rheological behavior of machined materials is usually described by a Johnson Cook law. However, studies have shown that dynamic recrystallization phenomena appear during machining in the tool/chip interface. The Johnson Cook constitutive law does not include such phenomena. Thus, specific rheological models based on metallurgy are introduced to consider these dynamic recrystallization phenomena. Two empirical models proposed by Kim et al. (2003) and Lurdos (2008) are investigated in machining modeling.

A two-dimensional finite element model of orthogonal cutting, using an Arbitrary LagrangianEulerian (ALE) formulation, is developed with the Abaqus/explicit software. Specific rheological models are implemented in the calculation code thanks to a subroutine. This finite element model can then predict chip formation, interfacial temperatures, chip-tool contact length, cutting forces and chip thickness with also and especially the recrystallized area.

New specific experiments on an orthogonal cutting test bench are conducted on AISI 1045 steel specimens with an uncoated carbide tool. Many tests are performed and results are focused on total chip thicknesses and recrystallized chip thicknesses.

Finally, compared to numerical results got with a Johnson Cook law, numerical results obtained using specific rheological models to take into account dynamic recrystallization phenomena are very close to experimental results. This work shows also the influence of rheological behavior laws on predicted results in the modeling of high speed modeling.
\end{abstract}

\section{Introduction}

The high-speed machining is subject to economic and ecological constraints. The improvement of the productivity, the reduction of the tool wear and the control of residual stresses of workpieces can be achieved by optimization of cutting process. The development of numerical approaches to accurately simulate phenomena occurring during high-speed machining is needed.

Very high pressures combined with sliding localized at the tool tip and on the cutting face speeds activate specific physical phenomena. Most studies on machining modeling as works of Watremez et $\mathrm{Al}$ in 2012 [1], Brocail et $\mathrm{Al}$ in 2010 [2] or Rech et al in 2009 [3] are conducted with a rheological Johnson-Cook model determined by Jaspers and Dautzenberg in 2002 [4]. However, this rheological model doesn't include microstructural phenomena which can occur in the tool-chip interface. In fact, the material can be subject to the dynamic recrystallization during machining 
because of strain rates higher than $10^{5} \mathrm{~s}^{-1}$ and Johnson Cook law is in that case no longer appropriated.

Some authors have established rheological models to consider dynamic recrystallization in modeling. Kim et al (2003) [5] or Lurdos (2008) [6] have recently suggested more appropriated numerical models for machining. Both models provide two sets of parameters: one for a nonrecrystallized material and another for a recrystallized material. A softening due to recrystallization is clearly visible on the rheological behavior of curves. Through a routine, these laws can be implemented in computer code. Some authors as Courbon et Al (2013) [7] have implemented the model of Kim et al [5] in Abaqus to predict the percentage of recrystallized material. Other authors such as Arrazola and Al (2014) [8] have changed the Johnson-Cook model to include a softening on behavior law. In addition to deformation, strain rate and temperature, a fourth term appears in the modified equation of Johnson-Cook to consider the softening. This method which consists to adjust the Johnson-Cook law is really appropriated when the entire studied area undergoes dynamic recrystallization phenomena. Contrary to the rheological models of Kim and Al [5] or Lurdos [6], this modified law does not include a parameter to check the recrystallization or not of the material. For models of Kim and $\mathrm{Al}$ [5] or Lurdos [6], a single set of parameters is assigned to the numerical model regardless of the dynamic recrystallization rate.

Rotella and Umbrello (2014) [9] have also used a modified Johnson-Cook law. In their work, they have combined this law with another law to determine with a numerical model the final grain size in chip area. However, the right use of this method needs to be ensured that the rheological model of Johnson-Cook is really identified for strain rates equivalent to those occurred during highspeed machining.

The dynamic recrystallization phenomena observed at the tool-chip interface are not the only target to hang into account to describe more carefully the contact in numerical simulations. Several studies focus on the development of advanced friction laws. Some authors consider the interface friction coefficient depending only on sliding velocity without consider influences of pressure and temperature. Rech et Al [3] have determined a friction model to describe the friction coefficient at the interface during machining of annealed AISI 1045 steel using TiN coated carbide tool. Recent works of Ben Abdelali et $\mathrm{Al}$ [10] (based on those of Rech [3]) allow to express again the friction coefficient as a function of sliding velocity. Brocail et $\mathrm{Al}$ [2] have conducted their study with the same antagonists as Rech [3] for low sliding velocities and high temperatures. These authors use an experimental device that simulates the behavior of tool-chip interface friction in the primary shear zone. Advanced friction law (Eq. 1) is defined by these authors from data collected by experimental and numerical simulations where $\sigma_{\mathrm{n}}$ is the normal pressure, $\mathrm{v}_{\mathrm{g}}$ local slipping velocity and $\mathrm{T}_{\mathrm{int}}$ local interface temperature.

$$
\mu=C_{1} \sigma_{n}^{C_{2}} v_{g}^{C_{3}} T_{i n t}^{C_{4}}
$$

Watremez and al [1] have also led study of the sensitivity of input parameters on predicted output parameters in numerical machining modeling. This analysis shows a significant effect of input friction coefficient on predicted cutting process parameters. They finaly insist on the importance of precisely define the friction coefficient in finite element models of machining.

For the present work, an experimental test enables to simulate orthogonal cutting. Several tests are then performed to provide experimental data in terms of chip thicknesses and recrystallized chip thicknesses. The following work is intended to compare the experimental results with the numerical results and highlight the use of rheological laws taking into account the dynamic recrystallization.

\section{Experimental results}

Tests of orthogonal cutting (Figure 1) are carried out for two cutting speeds $\left(40 \mathrm{~m} \cdot \mathrm{min}^{-1}\right.$ and $\left.64 \mathrm{~m} \cdot \mathrm{min}^{-1}\right)$ and four cutting depths $(0.1,0.2,0.3$ and $0.4 \mathrm{~mm})$. The results in terms of chip thicknesses are shown in Table 1. 


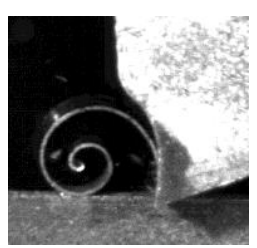

Figure 1 Orthogonal cutting test for a cutting speed of 64m.min-1 and a cutting depth of $0.2 \mathrm{~mm}$

Table 1. Experimental results in terms of total and recrystallized chip thicknesses

\begin{tabular}{|c|c|c|c|c|c|}
\hline & & \multicolumn{2}{|c|}{ Chip Thickness $\left(\mathrm{Th}_{\mathrm{Tot}}\right)$} & \multicolumn{2}{|c|}{$\begin{array}{l}\text { Recrystallized Chip Thickness } \\
\left(\mathrm{Th}_{\mathrm{r}}\right)\end{array}$} \\
\hline \multicolumn{2}{|c|}{ Cutting Speed $\left(\mathrm{V}_{\mathrm{c}}\right)$} & $40 \mathrm{~m} \cdot \mathrm{min}^{-1}$ & $64 \mathrm{~m} \cdot \mathrm{min}^{-1}$ & $40 \mathrm{~m} \cdot \mathrm{min}^{-1}$ & $64 \mathrm{~m} \cdot \mathrm{min}^{-1}$ \\
\hline \multirow{15}{*}{ Cutting Depth (mm) } & 0.1 & 0.33 & 0.27 & 0.08 & 0.089 \\
\hline & 0.1 & 0.33 & 0.28 & 0.083 & 0.072 \\
\hline & 0.1 & 0.33 & 0.28 & 0.083 & 0.073 \\
\hline & 0.1 & 0.35 & 0.28 & 0.083 & 0.07 \\
\hline & 0.1 & 0.35 & 0.3 & 0.086 & 0.075 \\
\hline & 0.1 & 0.4 & 0.3 & 0.088 & 0.075 \\
\hline & 0.2 & 0.48 & 0.44 & 0.096 & 0.08 \\
\hline & 0.2 & 0.49 & 0.47 & 0.098 & 0.085 \\
\hline & 0.2 & 0.57 & 0.48 & 0.11 & 0.09 \\
\hline & 0.3 & 0.67 & 0.68 & 0.10 & 0.09 \\
\hline & 0.3 & 0.75 & 0.7 & 0.12 & 0.11 \\
\hline & 0.3 & 0.76 & 0.74 & 0.13 & 0.12 \\
\hline & 0.4 & 0.9 & 0.88 & 0.11 & 0.12 \\
\hline & 0.4 & 0.95 & 0.91 & 0.14 & 0.13 \\
\hline & 0.4 & 0.96 & 0.94 & 0.15 & 0.14 \\
\hline
\end{tabular}

The geometry of these specific specimens is shown in Figure 2. A chamfer is used at the beginning of the sample in order to avoid the impact of the tool on the workpiece. Forces generated by the tool are reduced by the means of a cutting width equal to $3 \mathrm{~mm}$. The sample, made of AISI 1045 steel, measures $175 \mathrm{~mm}$ in the longitudinal direction to get a steady-state zone during the test. Before test, samples are subjected to a graphite annealing in order to reduce residual stresses due to machining during manufacture and to homogenize their microstructures of ferrite and pearlite.

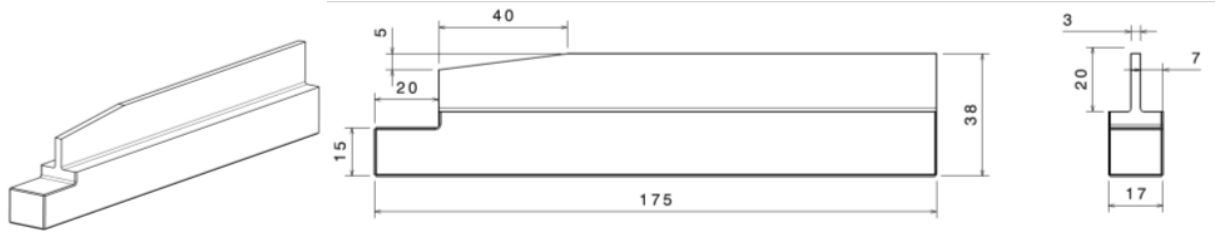

Figure 2 Geometry of the sample [mm]

A gooseneck tool is used to reduce the vibrations caused by the test bench. By its form, the tool is in abutment and fixed against the hydraulic ram. The uncoated cutting tool have a rake angle of $0{ }^{\circ}$ and a $4{ }^{\circ}$ clearance angle. The real speed of the tool is retrieved by using a high speed camera which captures 7000 frames per second fixed on the test bench. After the test, the chip is collected and coated with resin in an appropriate position. This coated sample is then cut to observe a chip section. This section is polished, attacked with a Nital 3\% solution during 10s and finally observed with an optical microscope.

\section{Finite element model for orthogonal cutting analysis}

A two-dimensional finite element model of the orthogonal cutting with an ALE formulation (Arbitrary Lagrangian-Eulerian) is developed on the Abaqus software. Only the chip formation zone is meshed (Figure 3). Quadrilaterals CPE4RT elements coupling movement in the work plan and the temperature are used in Abaqus explicit. For a depth of cut equal to $0.1 \mathrm{~mm}$, all elements of the chip formation zone are smaller than $10 \mu \mathrm{m}$. The rest of the mesh is composed of elements whose size ranging from 10 to $100 \mu \mathrm{m}$. The mesh is composed of elements 4247 for the sample and 
1665 for the tool. The tool with has an edge radius of $50 \mu \mathrm{m}$ and is modeled as a rigid body with a thermal conductivity.

In an orthogonal cutting, plastic deformations of the specimen in the primary and secondary shear zone and frictions at the tool/chip interface are two sources of heat. The Taylor Quinney coefficient converts mechanical energy into heat due to plastic deformations. In accordance with the work of Rosakis et al [11], the coefficient of Taylor-Quinney is set to 0.9. The heat flux produced at the interface is shared between the tool and the chip and $60 \%$ of the produced heat flow is assigned to the chip.

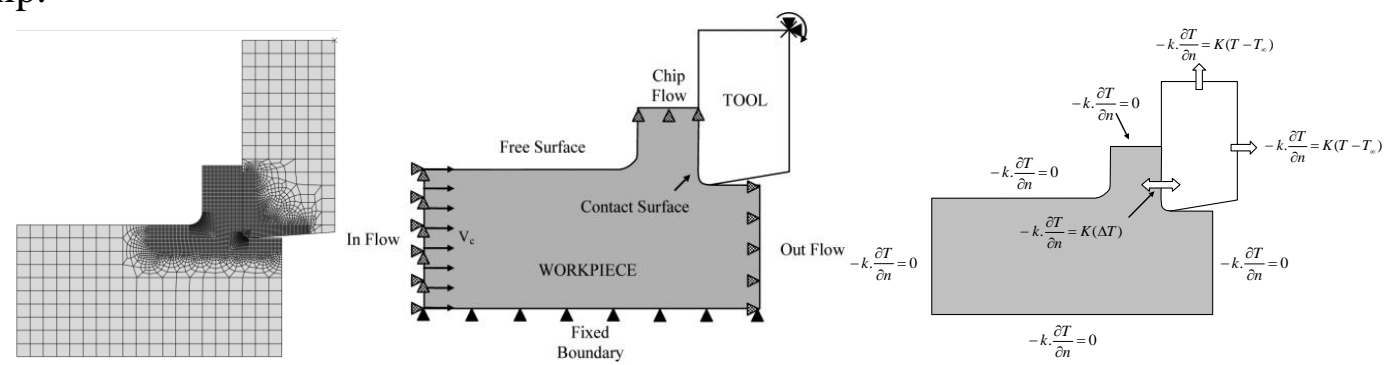

Figure 3 initial mesh and boundary conditions in displacement and temperature of the model

For this study and according to Brocail's work [2], friction at the tool/chip interface is modeled by a constant friction coefficient of Coulomb type equal to 0.4 . Tool and the specimen temperatures are numerically initialized to $20^{\circ} \mathrm{C}$. The contact between the workpiece and the tool is considered as thermally perfect. A high thermal conductivity of $10^{6 \circ} \mathrm{CW}^{-1} \mathrm{~m}^{-2}$ is applied in the contact.

The input parameters used for numerical models are given in Table 2. The thermo-physical properties of the tool (uncoated carbide H13A) are taken from the work of Kalhori (2001) [12]. The thermo-physical properties of the workpiece are extracted from work of Grzesik and Nieslony (2004) [13].

Table 2. Input parameters for numerical models

\begin{tabular}{|l|c|}
\hline Worpiece material & AISI 1045 \\
\hline Tool material & Uncoated carbide \\
\hline Cutting speeds & 40 and 64 $\mathrm{min}^{-1}$ \\
\hline Cutting depths & $0.1,0.2,0.3$ and $0.4 \mathrm{~mm}$ \\
\hline Cutting width & $3 \mathrm{~mm}$ \\
\hline Rake angle & $0^{\circ}$ \\
\hline Clearance angle & $4^{\circ}$ \\
\hline Coulomb friction coefficient & 0.4 \\
\hline
\end{tabular}

The rheological behavior law proposed by Lurdos [6] (Eq. 2) is used to take into account the dynamic recrystallization phenomenon in the interface and to describe the thermo-visco-plastic behavior of AISI 1045 steel. Each parameter of this model is described by its strain rate sensitivity $m_{i}$ and its normalization constant $K_{i}$. For this steel, these constants have been got by Courbon [14].

$$
\sigma_{y}=\sigma_{s}+\left(\sigma_{0}-\sigma_{s}+A \varepsilon_{p}^{n}\right) \exp \left(-r \varepsilon_{p}\right) \quad \text { with } \sigma_{i}=K_{i} \cdot Z^{m_{i}}
$$

Two sets of parameters reported in table 3 have to be determined for this law with reference to the variable $\mathrm{Z}$ which is the number of Zenner-Hollomon. The first parameter deals with a value of $\log (Z)$ less than or equal to 23 whereas the second parameter is related to a value of $\log (Z)$ greater than 23. The value of $\log (Z)$ allows to switch between recrystallized and non-recrystallized material. When this value falls below 23 , the first set of parameters is used and the recrystallization is counted.

Table 3. Lurdos parameters of AISI 1045 by Courbon (2011) [14]

\begin{tabular}{|c|c|c|c|c|c|c|}
\hline & $\log (\mathrm{Z})$ & $\mathrm{K \sigma}_{0}$ & $\mathrm{m \sigma}_{0}$ & $\mathrm{~K} \sigma_{\mathrm{s}}$ & $\mathrm{m \sigma}_{\mathrm{s}}$ & $\mathrm{K}_{\mathrm{r}}$ \\
\hline \multirow{2}{*}{$\mathrm{C} 45$} & $\leq 23$ & 223.87 & $2.521 .10^{-3}$ & 24.95 & $6.487 .10^{-2}$ & 0.652 \\
\cline { 2 - 8 } & $>23$ & 250.03 & $-2.928 .10^{-4}$ & 699.84 & $1.940 .10^{-3}$ & 9.931 \\
\hline & $\log (\mathrm{Z})$ & $\mathrm{m}_{\mathrm{r}}$ & $\mathrm{K}_{\mathrm{A}}$ & $\mathrm{m}_{\mathrm{A}}$ & $\mathrm{K}_{\mathrm{n}}$ & $\mathrm{m}_{\mathrm{n}}$ \\
\hline \multirow{2}{*}{$\mathrm{C} 45$} & $\leq 23$ & $5.090 .10^{-2}$ & 2070.14 & $-1.343 .10^{-2}$ & 4.682 & $-4.877 .10^{-2}$ \\
\cline { 2 - 8 } & $>23$ & $1.731 .10^{-3}$ & - & - & 0.452 & $-5.043 .10^{-3}$ \\
\hline
\end{tabular}




\section{Results analysis}

As an example, the results got for a configuration with a depth of cut of $0.1 \mathrm{~mm}$ combined with a cutting speed of $64 \mathrm{~m} \cdot \mathrm{min}^{-1}$ is shown by Figure 4 . The numerical results are compared with experimental results. Three areas with different microstructures can be distinguished. The first region is partially recrystallized and defined by a $\log (Z)$ between 32 and 23 . The second area is the hybrid area where $\log (Z)$ is between 23 and 21. Finally, if the value of $\log (Z)$ is less than 21 and more than 18 , the area is totally recrystallized. The results show also that the recrystallization phenomenon can't be perfectly predicted with the single value of $\log (Z)$ as indicator and the use of different ranges seem more judicious.

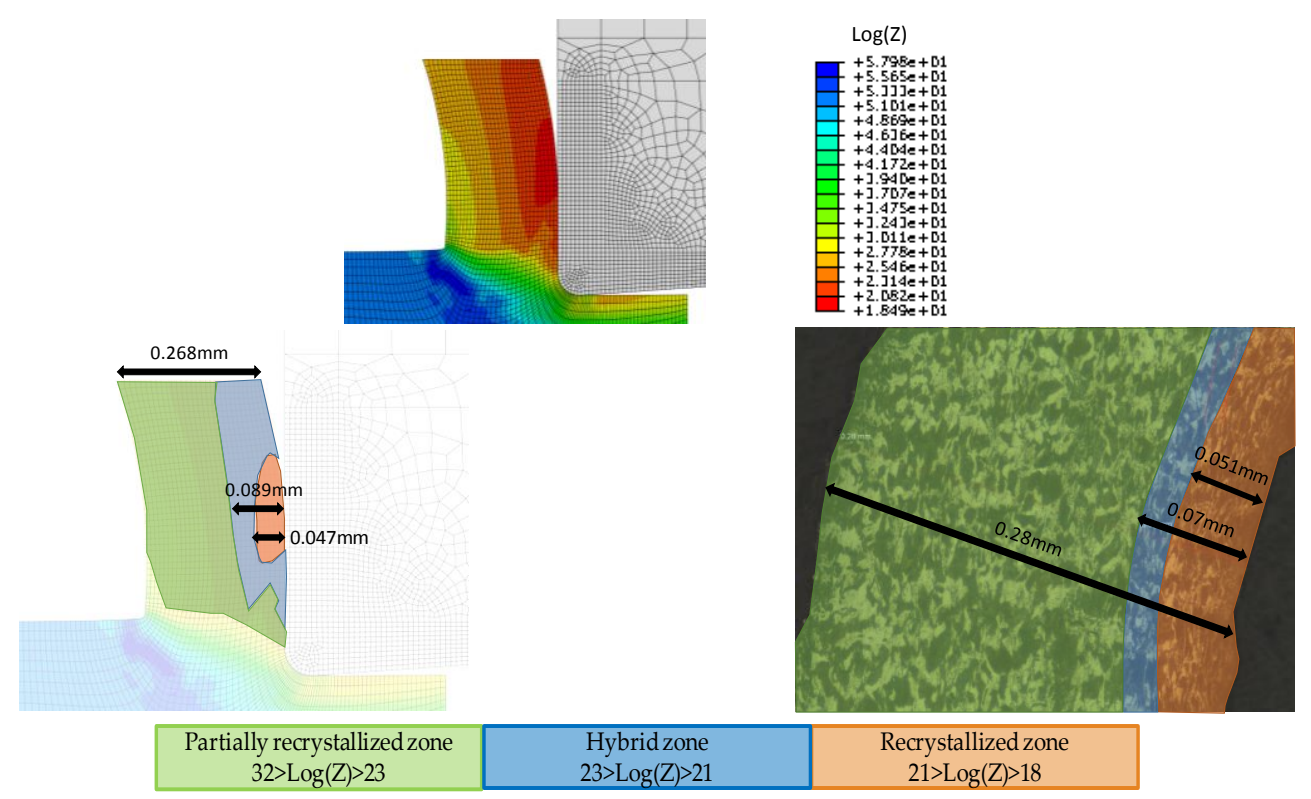

Figure 4 Experimental and numerical results (depth of cut $=0.1 \mathrm{~mm}$, cutting speed $=64 \mathrm{~m} . \mathrm{min}^{-1}$ )

Numerical results are very close to the experimental values. As illustrated on Figure 4, for a total experimental chip thickness equal to $0.28 \mathrm{~mm}$, a value of $0.268 \mathrm{~mm}$ is given by numerical simulation give and for a recrystallized experimental chip thickness of $0.07 \mathrm{~mm}$, the numerical model leads to a value of $0.089 \mathrm{~mm}$. In addition, on Figure 5 and Figure 6 , the curves in terms of thicknesses for the numerical results appear to be similar to the experimental results.

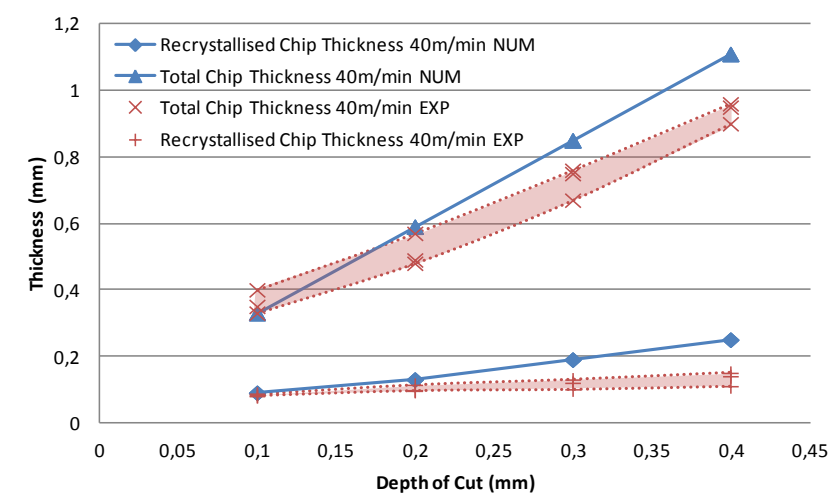

Figure 5 Results for a cutting speed of $40 \mathrm{~m} / \mathrm{min}$

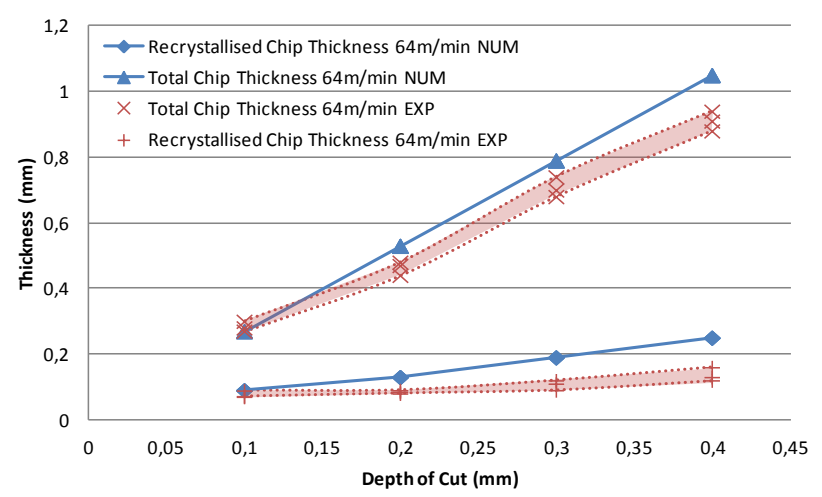

Figure 6 Results for a cutting speed of $64 \mathrm{~m} / \mathrm{min}$

\section{Conclusion}

Several experimental tests have been carried out on an orthogonal cutting test bench to simulate specific physical phenomena at the tool-chip interface for high-speed machining conditions. A 3D finite element model is also implemented in Abaqus Explicit. An ALE remeshing is used to eliminate elements distortions and crashed calculations. Experimental and numerical analysis of data showed the importance of using a specific rheological behavior law incorporating dynamic 
recrystallization phenomena. Indeed, the trend curves for numerical results appear to be similar to the experimental results curves in terms of total and recrystallized chip thicknesses. This work shows also that is more judicious to use different ranges of values for $\log (\mathrm{Z})$ rather than a defined value to predict recrystallized areas in chip thicknesses..

\section{Reference}

[1] M. Watremez, D. Meresse, L. Dubar et J. Brocail, «Finite element modelling of orthogonal cutting: sensitivity analysis of material and contact parameters,» International Journal of Simulation and Process Modelling, vol. 7, pp. 262-274, 2012.

[2] J. Brocail, M. Watremez et L. Dubar, «Identification of a friction model for modelling of orthogonal cutting,» International Journal of Machine Tools \& Manufacture, pp. 807-814, 2010.

[3] J. Rech, C. Claudin and E. D'Eramo, "Identification of a friction model - Application to the context of dry cutting of an AISI 1045 annealed steel with a TiN-coated carbide tool," Tribology International 42, pp. 738-744, 2009.

[4] S. Jaspers et J. Dautzenberg, «Material behaviour in conditions similar to metal cutting: flow stress in the primary shear zone,» Journal of Materials Processing Technology, pp. 322-330, 2002.

[5] S. Kim, Y. Lee et S. Byon, «Study on constitutive relation of AISI 4140 steel subject to large strain at elevated temperatures,» Journal of Materials Processing Technology, vol. 140, pp. 84 89, 2003.

[6] O. Lurdos, F. Montheillet, G. Damamme, Empirical and physically based flow rules relevant to high speed processing of 304L steel. International Journal of Material Forming, vol.1, pp. 1431-1434, 2008.

[7] C. Courbon, T. Mabrouki, J. Rech, D. Mazuyer, F. Perrard et E. D'Eramo, «Towards a physical FE modelling of a dry cutting operation: influence of dynamic recrystallization when machining AISI 1045,» Procedia CIRP 8, p. 516 - 521, 2013.

[8] P. Arrazola, A. Kortabarria, A. Madariaga, J. Esnaola, E. Fernandez, C. Cappellini, U. D. et T. Ozel, «On the machining induced residual stresses in IN718 nickel-based alloy: Experiments and predictions with finite element simulation,» Simulation Modelling Practice and Theory, pp. 87-103, 2014.

[9] G. Rotella et D. Umbrello, «Finite element modeling of microstructural changes in dry and cryogenic cutting of Ti6A14V alloy,» CIRP Annals - Manufacturing Technology, pp. 69-72, 2014.

[10] H. Ben Abdelali, C. Claudin, J. Rech, W. Ben Salem, P. Kapsa et A. Dogui, «Experimental characterization of friction coefficient at the tool-chip-workpiece interface during dry cutting of AISI1045,» Wear, 286-287, pp. 108-115, 2012.

[11] P. Rosakis, A. Rosakis, G. Ravichandran et J. Hodowany, «A thermodynamic internal variable model for the partition of plastic work into heat and stored energy metals,» Journal of the Mechanics and the Physics of Solids, vol 15, pp. 581-607, 2000.

[12] V. Kalhori, «Modeling and simulation of mechanical cutting,» $\mathrm{PhD}$ thesis, University of Lunea Tekniska, 2001.

[13] W. Grzesik et P. Nieslony, «Physics based on modelling of interface temperatures in machining with multiplayer coated tools at moderate cutting speeds,» International Journal of Machine Tools \& Manufacture, vol 44, pp. 889-901, 2004.

[14] C. Courbon, Vers une modélisation physique de la coupe des aciers spéciaux: intégration du comportement métallurgique et des phénomènes tribologiques et thermiques aux interfaces, Lyon, 2011. 